\title{
Governance of Public Pension Funds: Lessons from Corporate Governance and International Evidence
}

\author{
David Hess and Gregorio Impavido
}

Governments are paying increasing attention to the management of their public pension fund reserves. Rather than cutting benefits or increasing contributions to enlarge these reserves, they are focusing on the more politically appealing alternative of improving their investment performance (Palacios 2002). They are, however, facing growing pressure to use these funds to improve the local economy or achieve other social goals, and such use obviously can have a significant negative impact on investment performance. There consequently is a strong need for public pension reform to focus on the governance structures and practices of these funds.

There is extensive research on the governance of corporations. The field of corporate governance generally is concerned with the basic issue of instilling investors with the confidence that will permit them to hand over their money to managers. As noted by Davis and Useem (2000), corporate governance deals with the basic issue of "the ways in which suppliers of finance to corporations assure themselves of getting a return on their investment" (Shleifer and Vishny 1997: 737), as well as the broader cultural and institutional arrangements affecting the governance of firms. Over the past two decades, corporate governance has become a leading topic of discussion for researchers in finance, management, and law. Their goal is to find the 
optimal organizational arrangements to both protect shareholders' rights and at the same time increase economic efficiency.

A leading theory used to analyze corporate governance and provide prescriptions on governance structures and incentives is the agency theory. This paper examines the applicability of this theory to the governance of public pension funds. The first section discusses the application of agency theory to corporations. Included in this discussion is the problem of the separation of ownership and control, where certain inefficiencies result when those making the decisions for the organization do not fully bear the risks of those decisions. Corporations use various mechanisms to attempt to control these problems. The following section discusses the agency problems that may exist in public pensions. The next section provides an analysis of the control of agency problems that impact the management of pension funds, and demonstrates the need for a strong, well-functioning board of trustees. The section after that discusses the implications of using behavioral controls (as opposed to outcome controls) to solve agency problems associated with the structure and functioning of the board of trustees. This section also provides the results of a survey of 26 pension funds from various countries. ${ }^{1}$ Conclusions follow in the final section.

\section{Agency Theory and Corporate Governance}

\section{Agency Problems: Separation of Ownership and Control and Moral Hazard Problems}

Agency theory deals with the problems that can arise when one person (an agent) acts on behalf of another (the principal). Specifically, the delegation of authority to the agent may result in the agent taking actions that are not in the principal's best interests (i.e., that are acts of self-interest on the part of the agent) but which are unknown to the principal. The goals of agency theory are to constrain agents from acting improperly and to provide them with incentives to act appropriately.

In the context of the corporation, agency theorists view the firm as a "nexus of contracts" between shareholders, managers, and other stakeholders. These parties each may have conflicts of interests with the other contracting parties. For example, if a manager owned 100 percent of a 
firm's equity there would be no conflict of interest, as the manager would receive all the benefits of his or her efforts and would bear all the costs of any shirking or opportunistic behavior (Jensen and Meckling 1976). As the manager's fraction of the equity declines, the manager is more likely to "appropriate perquisites out of the firm's resources," and the manager's "incentive to devote significant effort to creative activities such as searching out new profitable ventures falls" (Jensen and Meckling 1976). When the manager's ownership moves toward zero percent of the corporation's equity, significant agency problems can result. This is the basic problem of separating ownership from control that dominates discussions of U.S. corporate law and finance-those making the decisions do not bear the full wealth consequences of their actions.

It should be noted that the problem of separation of ownership (the shareholders) from control (management) is rare outside of the United States and the United Kingdom. In other countries, corporations typically are owned by majority shareholders (Davis and Useem 2000). While such shareholders may take actions for their own benefit and to the detriment of minority shareholders, the presumption is that large shareholders work toward the increase of share value, and this is to the benefit of all shareholders. When control is exercised by small minority shareholders (management) the same presumption cannot safely be defended, for the reason that minority shareholders may receive more value from actions that provide a personal benefit at the expense of share value.

In addition to the issue of the separation of ownership from control, there are other problems that can afflict any type of agency relationship. These can result from uncertainty and goal conflict or from an inability to write a contract that fully specifies the behavior of the agent in all situations (Levinthal 1988). With respect to uncertainty, agency theorists have identified two categories of problem. First, there is the moral hazard problem, which involves an agent failing to exert the necessary effort to satisfactorily perform his or her job (shirking) or taking actions that benefit himself or herself at the expense of the principal (opportunism). These problems result from a lack of monitoring or ineffective incentives. Second, there is the adverse selection problem, arising when an agent lacks the competence to perform the job. This results from an inability or failure of the principal to verify the claimed skills of the agent.

The goal conflict problem results when the principal and the agent have different goals and it is difficult (and/or expensive) for the principal to 
monitor the agent's behavior (to ensure appropriate behavior) (Eisenhardt 1989). The source of the conflict can be the self-interest of the agent or simply different attitudes toward risk. Where the goals of the agent and principal do not conflict, uncertainty is not an issue as the principal can rely on the agent to act in furtherance of their shared goals.

A fundamental assumption of agency theory is that individuals are selfinterested and will act on that self-interest; that is, they are opportunistic. Whenever there is a conflict between the interests of the agent and the principal, the agent thus can be expected to act in his or her own self-interest. For example, in publicly held corporations, managers (the agents) are contractually bound to work in the shareholders' (the principal's) best interests, but if they know that they will not be monitored nor therefore potentially punished they may exert less effort than is appropriate (shirking) or take advantage of company resources for their own personal benefit. In such situations an agency problem will occur whenever management has an incentive to pursue its own interests to the detriment of shareholder interests. This is not to say that all managers are opportunistic, but the threat of opportunism is significant enough that preventative measures must be taken.

\section{Resolving Problems}

\section{Behavioral versus Outcome Controls}

The goal of agency theory is to find the most cost-effective governance mechanisms to solve any existing or potential agency problems. Governance mechanisms are generally either behavior-oriented or outcome-oriented (Eisenhardt 1989). Behavior-oriented mechanisms focus on the specific actions of the agent, and include, for example, information systems that allow the principal to monitor the agent's behavior. Outcome-oriented mechanisms focus less on the specific actions of the agent and more on the results the agent achieves. Such mechanisms include stock options for managers, thus rewarding them for achieving the goals of the shareholders (increased share value).

Choosing the appropriate category of governance mechanism to use depends on several factors, including the amount of goal conflict, the task performed, the degree of outcome uncertainty, and the measurability of the 
outcome (Eisenhardt 1989). The application of these factors is summarized in Table 2.1.

\section{Corporate Governance Control Mechanisms}

Because there are significant benefits to having a specialized managerial group running a corporation, certain agency costs can be tolerated. To mitigate these costs, the corporate governance system has various behavioral

Table 2.1: Agency Relationship Characteristics

\begin{tabular}{|c|c|}
\hline Risk aversion & $\begin{array}{l}\text { The less risk-averse the agent (compared to the principal), the better it is } \\
\text { to use outcome-based mechanisms, as such mechanisms pass risk on to } \\
\text { the agent }\end{array}$ \\
\hline $\begin{array}{l}\text { Outcome } \\
\text { uncertainty }\end{array}$ & $\begin{array}{l}\text { Where various factors beyond the control of the agent can create } \\
\text { significant variations in outcomes (such as government policies or } \\
\text { changes in the general economic climate), using outcome-based control } \\
\text { mechanisms becomes less attractive, as there is no clear link between job } \\
\text { performance and organizational performance. }\end{array}$ \\
\hline Goal conflict & $\begin{array}{l}\text { The less goal conflict there is between the principal and agent, the less } \\
\text { need there is to monitor the agent's behavior (as both principal and agent } \\
\text { are working towards the same goal). The choice of mechanisms depends } \\
\text { on risk sharing. }\end{array}$ \\
\hline $\begin{array}{l}\text { Task } \\
\text { programmability }\end{array}$ & $\begin{array}{l}\text { Task programmability is the extent to which the specific behaviors of the } \\
\text { agent can be established in advance. With highly programmed tasks, } \\
\text { the behavior of the agent can be easily monitored and behavior-based } \\
\text { mechanisms therefore efficiently used. }\end{array}$ \\
\hline $\begin{array}{l}\text { Measureability of } \\
\text { outcome }\end{array}$ & $\begin{array}{l}\text { Where it is difficult to measure the outcome or, the contribution of } \\
\text { each team member to an outcome, or where the outcome cannot be } \\
\text { meaningfully measured except over a long period of time, then behavior- } \\
\text { based mechanisms may be best. }\end{array}$ \\
\hline $\begin{array}{l}\text { Length of time of } \\
\text { the principal-agent } \\
\text { relationship }\end{array}$ & $\begin{array}{l}\text { With longer-term relationships, the principal is better able to collect } \\
\text { information about the behavior of the agent and can effectively use } \\
\text { behavior-based controls. With short-term relationships and less time to } \\
\text { learn about the abilities of the agent, outcome-based controls may be } \\
\text { more attractive. }\end{array}$ \\
\hline
\end{tabular}


and outcome-based control mechanisms. Some of these controls are external to the firm and some are internal.

\section{External Controls}

The first external control of managerial behavior is the market for corporate control. If a corporation is underperforming due to poor management, another organization will recognize the lost value and purchase the corporation from its shareholders. If management does not act in the best interests of shareholders it will thus lose control of the firm. For this market to work, however, the firm's share price must accurately reflect the behavior of management.

A second external control is the product (or service) market. If management is not appropriately doing its job (or is incompetent), the corporation will fail and go into bankruptcy. Competition in the product market thus disciplines management, especially where there is also a functioning labor market for top management; that is, managing a corporation into bankruptcy will have a negative effect on a manager's career prospects.

A final external control involves monitoring by large shareholders. A shareholder with a significant interest in the firm has an incentive to expend the resources necessary to monitor management and also to intervene when necessary. Rather than simply sell their shares if they disagree with how the firm is being managed, large shareholders have an interest in improving the firm.

The first two of these mechanisms are outcome-based controls. Shareholder monitoring, although shareholders may push for some outcome-based controls, is behavioral.

\section{Internal Controls}

The board of directors can serve as an information collection system for the monitoring of management behavior (Eisenhardt 1989), and as such has become broadly regarded by corporate governance activists, scholars, and practitioners as the best continuous, cost-effective monitoring device (Singh and Harianto 1989). For it to fulfill this role, however, directors must have the proper incentives-just as managers may have a conflict of interest with shareholders, so may directors. 
In the corporate governance literature it is common to distinguish between inside and outside (or independent) directors. Inside directors are managers of the firm, while outside directors have no employment relationship with the firm. Inside directors bring to the board extensive knowledge of the firm, but they are expected to have a conflict of interest with shareholders and through siding with the CEO to provide no protection against problems of moral hazard. They typically will support the CEO's interests over those of the shareholders because the CEO controls the trajectory of their careers within the firm (Lin 1996). Outside directors are generally considered to be sufficiently independent of the CEO to be capable of protecting the rights of those shareholders who may be harmed by the CEO's behavior.

Boards that include directors that represent all stakeholder groups are uncommon. While some corporations in Germany, for example, are required by law to have employee representatives on the board (typically on a twotiered board), the ability of these representatives to protect the rights of their constituents or to influence corporate policy is not clear. Studies have even suggested that shareholder representatives may act to specifically limit the impact of such employee directors; shareholder directors, for example, have been known to exclude employee directors from meetings at which sensitive information is discussed (Becht et al. 2002).

Concerns about the ability of inside directors to perform their role has led corporate governance reformers to push strongly for a more independent board. The National Association of Corporate Directors and the Business Roundtable both recommend that a board consist of a "substantial majority" of outside directors (Bhagat and Black 1999). The California Public Employees' Retirement System (CalPERS), a pension fund active in corporate governance reforms, even recommends that the only inside director on the board should be the CEO (Bhagat and Black 1999).

The empirical evidence of the effectiveness of an independent board in reducing agency problems nonetheless is ambiguous. Some commentators argue that it is difficult to establish a statistical relationship because the board is a poor monitor of management regardless of its ratio of inside to outside directors. The independence of outside directors furthermore has been challenged by those who claim that CEOs have significant control over the selection of board members and will only choose those who are sympathetic to their view (see Shivdasani and Yermack 1999; Zajac and Westphal 1996; Westphal and Zajac 1995; Wade et al. 1990). Other critics 
argue that any outside directors appointed with the support of the CEO are unlikely to challenge the CEO's actions (see Lin 1996; Main et al. 1995; Lorsch and MacIver 1989). Mechanisms to mitigate against CEO control of a board include legal and financial incentives to encourage directors to exercise their own judgment in protecting shareholder interests. The labor market can provide a similar incentive.

While the board serves as a behavioral control on management, the board's incentives are outcome-based controls. First, corporation laws create fiduciary obligations, including the duties of loyalty and care, for directors. The duty of loyalty involves conflicts of interests and the avoidance of actions that would benefit the director at the expense of shareholders. The duty of care requires a director to act with good faith and "with the care that an ordinarily prudent person would reasonably be expected to exercise in a like position and under similar circumstances" (American Law Institute [ALI] Principles, section 4.01). This requires that a director be well informed on the subject at hand and that he or she act in the best interests of the corporation. If directors breach their duties they may be personally liable for any loses resulting to the corporation. In the United States, the incentive effects of liability for directors are limited to only the most egregious abuses, as courts are reluctant to second-guess the business decisions of directors even if they have turned out to be disastrous for the firm.

A second form of incentives for directors is reputation capital. Several scholars have argued that directors are motivated to fulfill their monitoring role by a concern to protect their reputation in the labor market (Fama 1980; Fama and Jensen 1983b). Directors develop and maintain their reputations as "experts in decision control" (Fama and Jensen 1983b: 315). During a director's tenure on a board, the company's performance will determine the director's reputation. If the company performs poorly, the director's reputation will be tarnished. This can lead to the director being offered fewer, or less prestigious, board seats in the future (Lin 1996).

Third, directors are motivated to perform their duties based on their own equity stakes in the firm. This theory is based on the notion of a "convergence of interests" (Lin 1996: 918): that a director who holds equity in a firm and who acts on his or her own financial interests necessarily also is acting in the interests of other shareholders.

The corporate governance literature in law and financial economics is dominated by researchers who have used an agency perspective. Management literature researchers additionally have considered factors such 
as team dynamics and organizational cultures. For example, one of the few consistent findings from empirical research on boards is that the greater the number of board members, the worse the organizational performance. In general, any board with more than 15 or 20 members will likely have a negative impact on performance. This finding has held for studies both in the United States and elsewhere (Davis and Useem 2000). With an increasing number of members, the ability of the board to work together as a team diminishes and the willingness of a director to be actively engaged in board activities decreases (Davis and Useem 2000).

In recognition of the need for smaller workgroups, it is common to find corporations using separate committees for matters such as investments, audits, governance, and compensation of management. The investment committee is usually responsible for defining the investment policy of the fund. The audit committee is usually responsible for oversight of the external auditor, including its qualifications and independence; the performance of the corporation's internal audit function and external auditors; and the responsibilities of senior management to ensure that an appropriate system of controls exists to (a) safeguard of the assets and income of the corporation; (b) ensure the integrity of the corporation's financial statements; and (c) maintain compliance with the corporation's ethical standards, policies, plans, and procedures and with laws and regulations. The governance committee usually exercises general oversight with respect to the governance of the board of directors: it would review the qualifications of and recommend proposed nominees to the board and would be responsible for (a) evaluating and recommending to the board corporate governance practices applicable to the corporation and (b) leading the board in its annual review of the board's performance. The compensation and management committee usually reviews and approves the corporation's compensation and benefit programs, ensures the competitiveness of these programs, and advises the board on the development of and succession for key executives.

\section{Agency Problems in Public Pension Plans}

This section takes a closer look at public pension funds to determine potential agency problems. By taking a "nexus of contracts" approach to public pensions we can examine what the various stakeholders expect from public pensions and where there are potential conflicts. This discus- 
sion will also provide insight into who the principals (or "owners") of the pension plan are.

\section{Who Are Public Pension Fund Stakeholders?}

To develop an understanding of the appropriate governance structure of public pension plans it is necessary first to identify the stakeholder groups and their interests. The three key stakeholder groups relevant to this analysis are the plan participants, the government, and the taxpayers. The plan participants group includes active members (the current contributors), retired members (those currently receiving benefits), and survivors and dependents of plan participants. The membership of this group can be broad or limited, depending on whether the pension plan is a national scheme or a specific civil service group. This stakeholder group clearly has the most direct interest in the pension system's performance (Mitchell 2002). In the United States and the United Kingdom, the law governing private pension plans requires that the plans be managed solely in the best interests of participants and beneficiaries. This stakeholder group has an interest in the amount of their benefits, in the assurance that they will receive those benefits at a future date, and in the size of their contributions to the plan.

A second stakeholder group is the government, which has an interest in the administrative costs of running the plan and in the performance of the plan's assets, as these factors influence the amount of the government's contribution for DB plans. As an employer (in the case of civil service plans), the government is interested in the financial health of the plan for its impact on the ability to recruit new employees and retain existing employees (Mitchell 2002). In addition, the financial health of the plan can have an impact on pay and benefit negotiations with employee representatives. The government, however, may desire to use the plan's assets to further other government objectives, such as making investments to help the local economy.

Finally, taxpayers are natural stakeholders of any defined benefit (DB) public pension fund and any defined contribution (DC) scheme with minimum return guarantees. In a DB plan, the beneficiary is given set retirement benefits based on a formula that considers years of employment, salary, cost of living adjustments, and other factors. The pension fund sponsor must make sure that the assets of the fund are sufficient to provide for current and potential liabilities (i.e., the payment of benefits to retirees). In this 
situation, the taxpayer bears the ultimate obligation to maintain adequate funding levels. If a pension fund obtains sufficient market returns through investment, the government may lower its contributions to the fund, which means it may directly lower taxes or use those funds for other projects. If market performance is poor and liabilities exceed assets, the government will have to use taxpayer money to increase the plan's assets. This will result in either an increase in taxes or fewer available funds for other government services. Funding problems in civil service plans can have other effects for taxpayers: for example, significantly underfunded pension plans can reduce property values, due to the expectation of future tax increases, or reduce the bond or credit ratings of local government (Mitchell 2002).

\section{Potential Agency Problems}

In the same way that they can create problems for corporations, goal conflict and uncertainty can create agency problems for public pension funds. It is useful to consider two potentially separate problems: traditional problems based on the direct self-interest of trustees, such as self-dealing and corruption, or simply shirking; and problems based on the political goals of the trustees, such as the use of pension fund assets to further the social goals of the governing party. The latter occurs, for example, when the trustees, without considering the risk-return characteristics of the investment, direct the pension's assets toward investments that support local businesses and employment.

In the United States, unresolved agency problems based on self-interest often involve politically motivated actions, commonly when politically appointed or ex officio trustees make decisions not to further the beneficiaries' interests but to improve their own situation. For example, during her campaign for public office a former ex officio trustee of the New York City pension fund publicized the corporate governance activism in which she had participated as a trustee of the city pension fund (Romano 2001 and 1993). Critics argued that she had spent the fund's assets on corporate governance activism not because she believed it would improve the fund's performance but because it would bolster her reputation as a populist politician who would stand up against big business.

This category of agency problems also includes the exercise of direct financial self-interest, such as the use of pension fund assets to benefit friends and family of the board. In the United States, the trustees of a 
Maryland state pension fund were criticized for investing funds through a money manager that was a significant campaign donor to the state governor. Despite having consistently low performance, the money manager received fees that were significantly higher than those paid to other managers.

A further example of a politically based agency problem is the funding of local initiatives for their social benefit without appropriate weight being given to the risk-return characteristics of the investment. For example, a pension fund may choose to invest in a financially troubled local business to save the jobs that the company provides, but at a risk to the fund's assets, or government bonds may be purchased at lower than market interest rates to further the borrowing ability of the government. The trustees in such cases may be acting on their own initiative, perhaps in their role as a publicly elected official, or they may be acting under pressure from outside political parties. Other examples from the U.S. experience include decisions to select investment advisors based not on their performance but on a preference for in-state managers or to further affirmative action goals (Romano 1993). Such investment managers are likely to be small and unable to take advantage of economies of scale on transactions, which will reduce fund performance.

It is important to remember that the party in power chooses the goals served by politically motivated actions, and that other parties may oppose these goals. These actions thus may be a way for the ruling party to further its social goals without following the regular political decision-making procedure for resource allocation. For example, some commentators in the United States have raised concerns that the California Public Employees' Retirement System (CalPERS) is dominated by Democrats and that they are using the system's assets to attempt to bring about social change without regard to the direct financial health of the system (Walsh 2002). Such actions nonetheless may be widely supported by the public.

Romano (1993 and 1995) has argued that public pension funds with trustees who are susceptible to political pressure will perform significantly worse than those boards with politically independent trustees. United States Federal Reserve Chairman Alan Greenspan likewise has argued against the investment of social security funds in equities: "In sum, because I do not believe that it is politically feasible to insulate such huge funds from governmental influence, investing social security trust fund assets in equities compromises the efficient allocation of our capital." 
Given that politically motivated decisions may have broad popular support, as is arguable in the case of CalPERS, there remains much debate concerning the significance of agency problems founded in political motivations. Recognition of the need to control self-interest-based agency problems in contrast may be assumed to be universal. In a survey conducted for this paper of pension funds in various countries, two of the 26 respondents answered "yes" to the following question: "Has there been any serious case of fraud or other scandal that resulted in formal investigation in the last five years?" Their responses indicate that this is a problem that deserves serious consideration when structuring the governance of public pension plans. The next section considers the extent of the second type of agency problem.

\section{Political Involvement:}

\section{Government Restrictions and Social Mandates}

That there is political involvement in the investment choices of public pension funds is well known. This involvement can come in the form of legislation passed on the initiative of trustees or can involve mandates to make certain investments or prohibitions on other investments.

In the United States, the use of economically targeted investments (ETIs) was in the 1990s one of the most controversial issues facing public and private pension fund management. ETIs are investments in which the fund managers take into consideration not only the investment return but also the economic benefits to the local community (GAO 1995; Watson 1994). Examples of ETIs include California's investment of US $\$ 375$ million in single-family homes to help increase affordable housing and create jobs, Connecticut's investment of US $\$ 25$ million in a local company to save 1,000 jobs, and Pennsylvania's decision to provide favorable interest rates for home mortgages (Stevenson 1992). Another common ETI practice involves using pension funds to provide venture capital to in-state companies that may not be able to attract the attention of other venture capitalists (GAO 1995). Until recently, the National Pension Fund (NPF) of the Republic of Korea met a requirement to contribute to economic and social development by lending to the government at nonmarket rates and purchasing nontradable government bonds.

The Singaporean Central Provident Fund (CPF) similarly has many objectives in addition to its core objective of ensuring sufficient retirement benefits. It administers schemes covering housing, medical savings accounts, 
and education; it also permits extensive pre-retirement withdrawals for investment in real estate, financial assets, and even gold and commodities. The CPF has different accounts to which individual contributions are credited. The ordinary account can be utilized for financing housing purchases, for investments in approved shares and stocks, and to finance children's tertiary education. The special account is a true pension retirement account. The medical account is used to pay for hospital services, certain outpatient services, and catastrophic health insurance premiums. Contribution rates to the different accounts vary by age and for workers up to 35 years of age the contribution rates to the three different accounts are 26 percent, 4 percent and 6 percent, respectively (Chia and Tsui 2003).

Advocates of ETIs claim that such investments can be structured to obtain a market rate of return, but they face significant opposition. Proponents of ETIs further argue that gaps in the capital market leave certain socially desirable projects underfunded; opponents claim that the true motivation for these pension fund investments is political. In 1992, a lobbyist for CalPERS referred to ETIs as "politicizing" pension investments rather than "maximizing" them (Vise 1992). Nofsinger (1998: 89) argued: "[ETIs] are often highly visible projects that attempt to generate a public good in a concentrated, geographical region. The claimable political benefits of an ETI policy can be large and the costs of claiming them small. The agency cost that taxpayers bear is not visible at the initial investment because the costs are not realized until some distant time when an increase in funding is needed for the underfunded pension plan."

ETIs may be able to achieve an acceptable rate of return and taxpayers may be willing to take on the extra risk in exchange for social benefits, but few pension funds have established criteria for selecting ETI projects (Iglesias and Palacios 2000). They are thus entirely under the purview of the board or of the ruling political party.

In addition to the mandating of certain investments, political interference may also see restrictions placed on the types of investments a fund may make. For example, a pension fund may be restricted from investing in foreign markets or in anything other than government bonds. The difficulties presented by such restrictions are compounded where there are limited investment opportunities in the home country (Iglesias and Palacios 2000). Even where explicit developmental and social mandates do not exist, prohibitions on certain types of investments may be sufficient in themselves to ensure that funds are invested in social projects. The five public pension 
Figure 2.1: Investment Restrictions (percentage of funds surveyed)

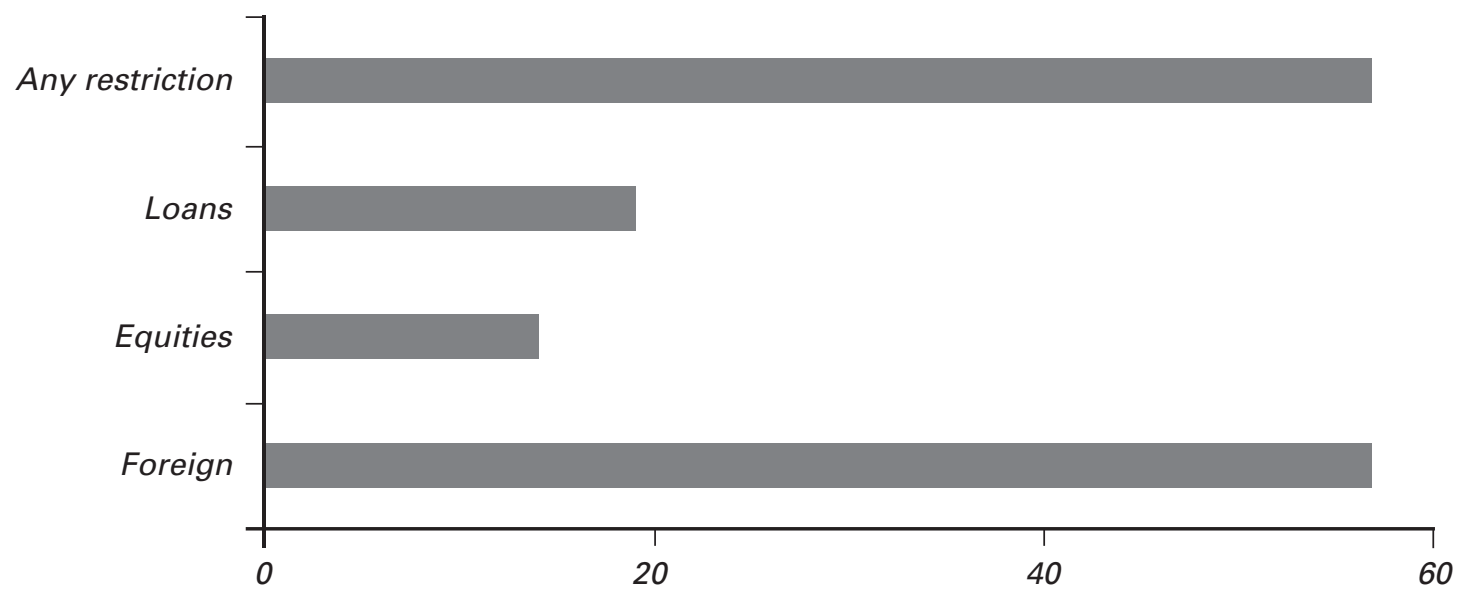

funds in Honduras that were surveyed for this paper do not have any explicit developmental mandate, but they are restricted from investing abroad. Attempts to diversify the fund's portfolio within the context of the limited domestic opportunities have seen approximately 30 percent of fund assets invested in housing loans to participants, often at a subsidized rate.

In Ghana, the Social Security and National Insurance Trust (SSNIT) is required to be invested in assets with adequate yield and liquidity and an acceptable risk level. Managers must follow basic portfolio theory rules for asset diversification as they seek to maintain an optimal funding ratio and to secure long-term rates of return for the fund (Dei 2001). However, the SSNIT investment policy includes social and developmental mandates in the following areas: housing finance, student loans, and industrial estates. Although returns on these assets were not reported, Dei comments that the student loan scheme has become a burden for the SSNIT. These loans are provided to students (including university students) at a subsidized interest rate. While the number of students has increased considerably, postgraduate unemployment also has increased, creating a further burden on the system. The loans furthermore are indexed to inflation, and as they increase in size, 
Public Pension Fund Management

Figure 2.2: Investment Mandates (percentage of funds surveyed)

2

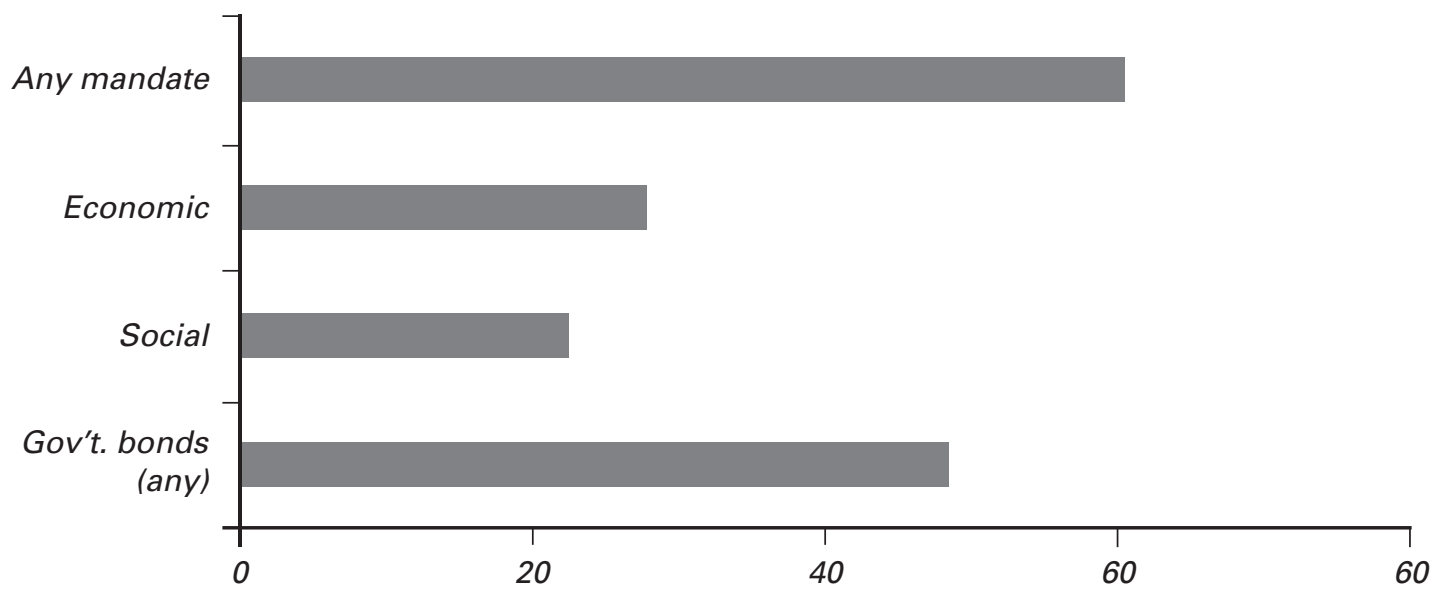

government delays in the payment of interest subsidies to the SSNIT again increase the overall burden on the fund.

This paper's survey of public pension funds around the world revealed that the use of restrictions and mandates is widespread. The most common restriction is on foreign investments, with 57 percent of the surveyed funds facing prohibition on investment abroad. Other restrictions include prohibitions on equities (14 percent) and loans (19 percent) (see Figure 2.1).

Explicit investment mandates also are common, with 60 percent of the funds operating under at least one type of mandate. These mandates include requirements to invest in government bonds (including national, state, provincial, and municipal bonds) (48 percent), in social projects such as housing (24 percent), and in general economic development obligations (32 percent). The use of restrictions and mandates furthermore may be more widespread than these figures indicate, as trustees may self-impose these investment practices on the fund in the absence of explicit requirements. 


\section{The Effects on Fund Performance}

One result of policies that seek to fulfill social objectives beyond fund value maximization is poor asset allocation, which in turn may lead to low investment returns. Recent studies show that asset allocation can explain up to 90 percent of the variability in the return on assets over time (Brinson et al. 1986; Brinson et al. 1991). Where asset allocation decisions are based on politics rather than on sound portfolio theory, investment performance is sure to suffer-to the extent that in some countries public pension fund returns are consistently lower than the interest rate paid by banks to individual savings accounts in those same countries (Iglesias and Palacios 2000).

Table 2.2 illustrates the portfolio allocations of the funds surveyed for this paper. The average fund has 35 percent of its assets allocated to government bonds, 25 percent to bank deposits, and 15 percent to equities. More than 20 percent of the funds have at least 80 percent of their assets allocated to government bonds or bank deposit, with the average fund having 60 percent of its assets in either government bonds or bank deposits. Almost onequarter of the sample have no investments in equities, and approximately two-thirds have less than 10 percent of their assets in equities. By contrast, analysis of 111 U.S. state and local pension funds from 2000 revealed the average fund to have 59 percent of its assets allocated to equities. ${ }^{2}$

The funds in our international sample used a wide range of asset allocations. Examination of the minimum and maximum portfolio allocations demonstrates this variety: while some funds face restrictions on investments in loans, one fund has invested 39 percent of its assets in loans. Another fund has more than half of its assets in real estate.

Table 2.2: Allocation of Assets for 26 Pension Funds (\% of Portfolio)

\begin{tabular}{lcccc}
\hline Investment type & Average & Median & Minimum & Maximum \\
\hline Government bonds & 35 & 20 & 0 & 98 \\
Bank deposits & 25 & 23 & 0 & 93 \\
Equities & 15 & 7 & 0 & 63 \\
Loans & 6 & 2 & 0 & 39 \\
Corporate bonds & 4 & 2 & 0 & 22 \\
Real estate & 8 & 2 & 0 & 52 \\
Other & 4 & 1 & 0 & 23 \\
\hline
\end{tabular}




\section{Solving Agency Problems}

\section{Separation of Ownership and Control}

A fundamental problem with public pension funds is how to achieve a workable separation of ownership and control. For example, if the plan participants are taken to be the owners of the fund, problems may result where another group (of, for example, government officials) controls the pension fund. This section considers the implications of the separation of ownership and control on pension plan governance. It considers first the situation of private pension plans and then the more complex problem of public pension plans.

\section{Ownership and Control in Private Pensions}

Recent work by Besley and Prat (2002) applies agency theory to private pension fund governance. Their goal was to find the optimal governance structure of defined contribution (DC) and defined benefit (DB) pension plans with respect to three potential sources of agency problems: the responsibility for monitoring the asset manager ("vigilance"), asset allocation decisions, and the plan's level of funding. Governance structure matters because, due to the inability to exactly specify the obligations of all parties, the plan's beneficiaries and sponsor do not have complete contracting ability. Thus, the incentives are important that encourage the parties to monitor or make appropriate asset allocation decisions. The optimal governance structure is one in which the risk-bearer is also the decision-maker (that is, there is no separation of ownership from control).

Determination of the optimal governance structure requires that the owner of the plan (which may also be termed the risk-bearer or residual claimant) be identified and if possible granted decision control responsibility. The residual claimant is the group with the greatest incentive to act with vigilance because it is this group that is best positioned to enjoy the benefits of such actions. For DC plans, the residual claimant is the beneficiary, as benefits suffer from poor financial performance but increase with better financial performance. For DB plans, because the benefits such plans do not change with the performance of their assets the residual claimants are the sponsors, as it is the sponsors that bear the risks of poor financial 
performance. If the beneficiaries have a comparative cost advantage in acting with vigilance, the plan therefore should be structured as a DC plan. If the sponsors have a comparative advantage, the plan should be structured as a DB plan.

This model considers only a single sponsor and a single beneficiary. With joint residual claimants, such as multiple beneficiaries, potential free-rider problems may reduce the incentive to monitor. That is, while the costs to monitor the asset manager would be borne by a single beneficiary, all beneficiaries would enjoy the benefits equally. This is similar to the problem of shareholders that have small ownership stakes in a corporation. For DC plans in which the residual claimants include numerous beneficiaries, we would argue that there is a strong need for a third-party monitor, such as a board of trustees. These trustees could be either insiders or outsiders. (Insiders are plan beneficiaries, hereafter referred to as "member trustees" to avoid confusion with insider directors of corporations.) Member trustees have an incentive to monitor as they have a financial interest in the plan as well as a bond with the other beneficiaries (for example, coworkers and friends), but they typically have little financial expertise. Outsiders, in contrast, are trustees with professional skills related to monitoring but with no financial interest in the plan (hereafter referred to as "professional trustees"). As an incentive for the professional trustees, their role should have a strong reputational effect. For such an incentive to exist there must be present an efficient career market for the trustee and a direct link between monitoring and the rate of return on assets. Defined benefit plans ideally should rely more on professional trustees, while DC plans should use self-motivated member trustees (as they are part of the residual claimant group).

With respect to asset allocation decisions, the implications of residual status on choice of governance are similar. The residual claimant is the efficient asset allocator. For example, the sponsor in a DC plan is not an efficient asset allocator because it does not fully bear the costs of its decisions and may have an incentive to invest in its own interests (for example, to overinvest in the sponsor company's stock). In DB plans the sponsor again may not be an efficient asset allocator if, for example, it has limited liability for the insolvency of the plan: with limited liability, the sponsor may be willing to take on excessive risk.

Consistent with agency theory, Besley and Prat (2002) argue that if decision-makers do not bear the full cost of their decisions inefficiencies can result (Fama and Jensen 1983a). These inefficiencies can have a significant 
impact on the residual claimant. With respect to private pension plans, the identification of the residual claimant is necessary to determine the most effective governance structure. Besley and Prat argue that for DC plans the beneficiary is the residual claimant, but for DB plans it is the sponsor. However, the sponsor in a DB plan is a qualified residual claimant to the extent it has limited liability for insolvency of the plan.

\section{Ownership and Control in Public Pension Funds}

The identification of the residual claimant is less straightforward in public pension plans. In the context of civil service public DB plans that are not pay-as-you-go, Murphy and Van Nuys (1994) argue that the residual claimants are the taxpayers. Because benefits are defined, funding problems with the pension plan may fall not on the beneficiaries but on the taxpayers, who must put up funds to cover unfunded liabilities. This argument holds to the extent that benefits paid to plan participants cannot be reduced. If benefits can be reduced, the plan participants (especially those retired members currently receiving benefits) are also residual claimants. In addition, where poor management of the pension plan's assets leads to an increased contribution rate for the plan participants, current plan members also have a status similar to that of residual claimants. One potential difference between beneficiaries and taxpayers, however, is the ability of beneficiaries to more completely protect their interests through contractual relationships with the pension plan sponsor.

For DC plans, the residual claimants are the beneficiaries. This stakeholder group bears the cost of poor asset management in the form of lower retirement benefits, although it may be the case that there is a guaranteed minimum rate of return on the assets. It also may be that government practices create an implicit guarantee that if market returns become so low as to render such pension instruments ineffective, the government will finance the retirement benefits of those with less than a politically acceptable cash balance in their retirement accounts. In such a case, the taxpayers again are the residual claimant.

Overall, there may be multiple different groups claiming residual claimant status and that therefore have the incentive to monitor the performance of the pension plan. To the extent that both taxpayers and beneficiaries are residual claimants, a basic application of agency theory would dictate that both should have decision control rights, including asset allocation 
decisions, the monitoring of asset managers (including hiring, firing, and establishing compensation agreements), and other management decisions. Of course, these groups may have significant conflicts with respect to how the plan should be managed. For example, a pension fund's increased performance can either be distributed to the plan members through higher cost-of-living adjustments and lower employee contributions, or it can be distributed to the taxpayers through a lowered government contribution. The exact allocation of decision control rights will depend on the structure of the pension plan. For example, in a DC plan without minimum guarantees the taxpayers are not residual claimants and the decision control rights should go to the plan participants, who bear the wealth consequences of their choices (see Murphy and Van Nuys 1994).

For national and civil service pension schemes (in which the beneficiaries are a more clearly defined group of individuals), the widely dispersed nature of the beneficiaries means that they must exercise their control through trustee representatives. These representatives, however, may not bear sufficient wealth consequences of their decisions for there to exist for them the incentive to avoid moral hazard problems or to maximize pension value. They may in this sense be similar to Besley's and Prat's (2002) professional trustees of private pensions and require external incentives such as the external labor market. Likewise, for corporate boards directors have an incentive to perform well to develop their reputations as "experts in decision control" (Fama and Jensen 1983a: 315). In both cases, the trustees/directors have incentives to do their job appropriately and with vigilance, because their actions will be rewarded or punished in their future career paths.

A similar analysis should be conducted for public pensions. That is, we should ask if there is an external labor market for trustees that will take into consideration a trustee's performance on the board. In many ways, the external labor market works as an outcome control, but there are problems with using outcome controls for public pensions. Namely, will the external market make a direct link between the trustee's monitoring performance and the fund's performance? It is quite possible that the market would only punish poor performance and would fail to reward solid performance. For example, many trustees in the United States fear negative publicity should their fund perform poorly but expect no reward (financially or from the media) for a strong performance. There is an incentive as such to concentrate on the avoidance of negative publicity rather on maximizing the fund's value. Additionally, the labor market for some trustees is the political market, 
engendering a motivation that can worsen agency problems rather than serve as a control mechanism, as trustees may use the fund's assets to win the favor of certain constituency groups. In such situations the use of self-motivated member trustees may be needed. This solution will work better for civil service pension plans than for national schemes, because the member trustee will have a closer bond to the plan (as argued in Besley and Prat [2002]).

\section{Implications for Governance}

The above analysis demonstrates the importance of involving the residual claimant in monitoring and control, and its value in reducing the inefficiency caused by the separation of decision-making from risk-bearing. For example, consider the decision of whether or not to allocate assets to economically targeted investments, which may or may not have similar risk-return characteristics to other investment options: In the case of a DB plan, where there is no chance of raising participant contribution rates or lowering benefits, the taxpayers are the sole residual claimants and their representatives on the board (government officials) bear the risk. In such a situation, the decision-making would be efficient if there were sufficient incentives for the board to perform its job appropriately.

The challenge facing public pension fund managers is how to create the appropriate controls and incentives for trustees. To determine which governance mechanisms are appropriate, it is necessary to identify for which behaviors the trustees would be rewarded or punished. Recalling some of the agency relationship characteristics identified by Eisenhardt (1989), we see that there are problems with using outcome controls. Most indicators point toward the use of behavioral controls. A key governance characteristic is outcome uncertainty. Many factors beyond the control of trustees can affect the performance of a fund; for example, limited local investments or short-term economic downturns can greatly affect performance. Likewise, there is a problem with the measurability of the outcome. Should the trustees be judged against a standard of short-term returns or consistent long-term performance? It is as difficult to make an interim judgment of performance toward a long-term goal as it is to accurately assess the worth of an investment decision based on the achievement of short-term goals. Furthermore, it is difficult to determine the contribution of any single trustee toward the accomplishment of a goal, and this creates the potential for a free-rider problem. 
To the extent that there is goal conflict between the agent and principal (for example, whether to invest the fund's assets for value maximization or invest them to achieve other social goals), there also is a need for behavioral controls. This is especially true for public pensions, as decisions to invest in ETIs may not significantly affect investment performance until years in the future, and possibly after the trustees supporting the initiative are no longer on the board. Likewise, decisions on actuarial assumptions or benefits may produce little change in the short run while creating significant long-term costs.

All of these factors support the use of behavioral rather than outcome controls for trustees. These potential controls are discussed in the next section. First, however, there is a discussion of the limitations of external controls. The corporate governance system relies heavily on external controls, but no such controls are available for the governance of public pensions. This further demonstrates the importance of a governing board to public pensions.

\section{External Controls}

There are three types of external controls for corporations: the product market, the market for corporate control, and large shareholders. Should managerial agency problems reach the point where they significantly harm performance, a corporation may go bankrupt (fail in the product market) or be taken over by another organization (fail in the market for corporate control).

These external controls are available neither for national public pension plans nor for civil service plans. In a centralized system, participants are unable either to shift their assets from one plan to another or to withdraw their assets from the plan. There is thus no equivalent of a product market. For civil service plans, the quality of those plans may have an effect on employee recruitment and retention, and failure to recruit employees may arguably be seen as equivalent to failure in the product market. However, in matters of finance, money is provided for a future payment and it is difficult for an outsider-in the case of a public pension plan, the plan participants- to determine if there is a problem with the use of those funds. This is in contrast to a consumer product purchase, where the consumer can typically and readily ascertain if there is a problem (Caprio and Levine 2002). This problem increases where there is inadequate disclosure, because in such cases the portfolio composition of pension funds can easily be altered 
without the knowledge of the fund's stakeholders. There thus are significant limits on the capability of the participant labor market to discipline management of the pension fund.

Nor is there a market for corporate control, as the plan participants do not have an ownership interest that can be traded on a secondary market. In addition, the fact that ownership interests are nontransferable means that other mechanisms of the corporate world, such as managerial ownership and equity incentives, are also not available (Mayers et al. 1997). Finally, because everyone's ownership interests are essentially equal, there is no possibility of a single shareholder emerging with an incentive to monitor the organization's performance. A group may serve this role-for example, a labor union may represent the interests of its membership with respect to the pension fund-but different unions within the general taxpayer population may have disagreements on how the fund should be managed. This is in contrast to the corporate situation in which shareholders can be assumed to have the same interest (increased share value).

In situations where external controls are not available, agency theory predicts a greater emphasis on the board as monitor. In other words, the various control technologies can substitute for one another. For corporations, this means that where a market for corporate control is not available greater emphasis will fall on the outside directors on the board. Mayers et al. (1997) supported this substitution hypothesis in a study of mutual and stock insurance companies. In mutuals, ownership rights are connected with customer insurance policies and therefore are nontransferable. In stock companies, ownership rights are not connected with policies and are freely transferable. Compared to stock insurance companies, mutuals are significantly more likely to have either a majority of outside directors on the board or a majority of outsiders on standing committees. The presence of outsiders also reduces management's consumption of perquisites, such as salary, while other costs that do not involve a conflict between management and owners are not significantly different.

\section{Implications for the Governing Body of Public Pension Plans}

Public pension funds thus clearly need a strong governing body. Compared to corporations, for which there are available a variety of external and 
internal control mechanisms, for public pensions the board is essentially the only available control. The following sections provide an initial analysis of the issues that should be addressed when creating a board that has the appropriate incentives to be an effective monitor and manager of a fund. Using Eisenhardt's terminology, these are mostly behavioral rather than outcome controls.

\section{Board Composition}

The trustees of U.S. civil service plans generally fall into one of three categories: they are elected by plan participants, appointed by the government, or serve as ex officio members. Trustees may be elected by either active employees or retired plan members, and they themselves may be active or retired members. Appointments are typically made by a chief elected official such as the governor or mayor or by a governing body such as a legislative committee, and often are made to provide representation for stakeholder groups in cases where beneficiary groups are not allowed to directly elect their own representatives. Ex officio trustees will serve on the board by virtue of their holding a particular public office, such as that of state treasurer or controller.

As discussed earlier, corporations have both inside directors and outside directors. Inside directors are also managers of the corporation in question, and can be either the source of moral hazard or lack the incentives to control moral hazard problems originating with the CEO. For public pensions, moral hazard problems (or goal conflicts with plan participants) typically are rooted with those trustees that also are government officials or that are appointed by government officials. A government may be able to bypass the board to use a fund's assets for other social or political goals (Iglesias and Palacios 2000), but it also may be able to achieve the same result if the board is dominated by trustees sympathetic or otherwise allied to it. Government-affiliated trustees are effectively the equivalent of corporate insider trustees.

Member trustees that are elected by plan members are not subject to the same political pressures as ex officio and appointed trustees. In this sense, their political independence makes them analogous to independent, outside directors on corporate boards. Just as outside directors theoretically are able to focus on shareholder interests without undue influence from corporate insiders, so too are member-elected trustees able to focus on beneficiary 
interests without undue political interference. They may also serve to monitor politically affiliated trustees. Trustees appointed by the government to represent specific stakeholder groups also may fall into this category, depending on how they came to be selected for appointment.

The composition of the board for a national pension plan is likely to differ from that of a board for a civil service plan. In the United States, for example, there are hundreds of state and local pension plans for civil servants, including those for teachers, judges, police, and firefighters. In such cases, plan members may be able to usefully elect their own representative. For national schemes, however, the election of trustees may not be feasible and may actually undermine the pension fund's goals (Palacios 2002). Instead, national schemes often have a tripartite board, with board members nominated to represent unions, employers, and government.

Analysis of a data set of more than 200 state and local U.S. civil service plans in the 1990s showed the composition of trustees on the average board to be approximately two-thirds with political affiliations and one-third elected by plan members. On average, almost one-half of the trustees were appointed by government official or committee and one-third were not members of that pension plan. The size of the board averaged 8.5 trustees, with a range of 3 to 32 trustees.

For our sample of 26 public pension funds, the number of trustees on the board averaged 12, with a range of 3 to 29 (see Table 2.3). The average proportion of ex officio trustees on the board was just less than 20 percent, and 70 percent of trustees were appointed. In 10 of the 26 plans, the entire board consisted of government-appointed members. Only eight of the 26 respondent funds had at least one trustee that was elected to the board. Instead of elected members, it was not uncommon for government-appointed trustees to represent trade unions or other employee associations: approximately 25 percent of board members represented trade unions or other employee associations and less than 15 percent represented employers. Approximately 40 percent of the board therefore could be classified as "outside" directors under the corporation analogy, as they are potentially independent of the government. This is approximately the same percentage as for U.S. state and local pension plans. However, while these trustees are appointed to represent different stakeholder groups, government influence may impact their ability to act as an independent monitor.

A final issue with respect to trustees that act as representatives of different groups is the expertise of those trustees. Only 62 percent of the 
Table 2.3: Board Composition (fraction of board)

\begin{tabular}{lccccc}
\hline & $N$ & Minimum & Maximum & Mean & Median \\
\hline How selected to board: & & & & & \\
Ex officio & 26 & 0.00 & 0.85 & 0.1850 & 0.0000 \\
\hline Appointed & 26 & 0.09 & 1.00 & 0.7044 & 0.8167 \\
\hline Elected & 26 & 0.00 & 0.91 & 0.1407 & 0.0000 \\
\hline Trustees representing specific groups: & & & & \\
\hline Trade unions & 25 & 0.00 & 0.62 & 0.1844 & 0.2000 \\
\hline Employers' association & 25 & 0.00 & 0.38 & 0.1291 & 0.0000 \\
Other employees' association & 25 & 0.00 & 0.38 & 0.0885 & 0.0000 \\
\hline Government as plan sponsor & 25 & 0.00 & 1.00 & 0.3104 & 0.2500 \\
\hline
\end{tabular}

funds surveyed indicated that they had at least one expert or professional member on the board, but among these funds on average 47 percent of trustees were identified as experts. One fund indicated that all of its four trustees were experts.

\section{Nomination and Termination}

An independent and vigilant board requires trustees that are not subject to political influence and that are free to exercise their independent judgment. These are the reasons behind the strong push toward corporate governance for boards dominated by outside directors. It is feasible for the participants of smaller civil service pension plans to directly elect some outside trustees, but for national schemes this may not be possible. Instead, the government may appoint trustees to represent stakeholder groups or to bring independent expertise to the board. The government's involvement in such appointments inevitably raises the concern that the trustees selected will be biased toward the government's policy goals and therefore will not be truly independent, however.

The equivalent situation on a corporate board would be that of the CEO selecting outside directors; should this occur, these directors at a minimum could be expected to be sympathetic to the CEO's views and therefore to be incapable of providing independent monitoring (Zajac and Westphal 1996; 
Main et al. 1995). The corporate governance solution to this problem has been to establish a nominating committee comprised entirely of independent directors. While the CEO will still have some influence in selecting new directors, it will be minimized. It is also recommended that the committee have fixed criteria for the selection of new directors, to ensure that the directors are qualified and to provide another control against favoritism in the selection process. Some public pension funds are experimenting with similar mechanisms.

The Canadian Pension Plan Investment Board (CPPIB) provides one example of how a pension fund is attempting to depoliticize the nomination of public pension plan governors (MacNaughton 2001). For the CPPIB, the federal finance minister and the finance ministers of the nine participating provinces appointed a nominating committee. Each government nominated one committee member, and the federal finance minister chose a private sector CEO as chair. For trustees, the committee identifies a set of qualified (as previously defined) prospective candidates from across Canada, referring this set to the federal finance minister. The federal finance minister then consults with his provincial counterparts on the proposed names before making final selection from the list recommended by the committee.

In New Zealand, the Minister of Finance appoints a committee to nominate potential trustees of the New Zealand Superannuation Fund. At least four members of the nominating committee must have work experience qualifying them as investment professionals. The Minister of Finance must then consult with parliament before recommending the nominees to the Governor General for appointment (Palacios 2002). The board is only responsible for investments, however: should this model be applied to a board that has control also over such matters as benefits, there are additional concerns that first should be taken into consideration.

It is also important that there be set procedures for the removal of trustees, to permit the fair removal of those that abuse their position while preventing the arbitrary removal of those who are performing their job. Trustees that are not subject to arbitrary termination are more likely to exercise independent judgment and less likely to bow to outside pressures (Carmichael 2002). The termination of a trustee should be fully disclosed to all interested stakeholders and should be made in accordance with predetermined processes and conditions of termination. The CPPIB appoints trustees on the basis of three-year terms, renewable three times, and no director may be removed from the board during his or her term in office for any reason other 
than illegal or immoral conduct. In New Zealand, by contrast, the Minister of Finance may remove any board member for any reason that the minister deems appropriate (Palacios 2002). In our sample of pension funds, only one-third of the funds surveyed had written criteria establishing acceptable causes for dismissal.

\section{Accountability}

The governing body should have a clear understanding of to whom they are accountable. In corporations, it is clearly understood that the board is accountable to the shareholders. For public pension funds, in contrast, there can be ambiguity on the issue of accountability. There are two possible groups of residual claimants, taxpayers and plan participants, and trustees may view themselves as being accountable to one or both of these stakeholder groups. They also may see themselves as being accountable to the political administration in power. In the United States, law mandates that private pension plans be managed solely in the best interests of the plan participants, and the trustees thus are accountable only to those participants. In some countries the same applies to public pension funds. For example, the Canada Pension Plan Investment Board Act directs the board "to manage any amounts that are transferred to it... in the best interests of the contributors and beneficiaries under that Act; and to invest its assets with a view to achieving a maximum rate of return, without undue risk of loss, having regard to the factors that may affect the funding of the Canada Pension Plan and the ability of the Canada Pension Plan to meet its financial obligations" (Palacios 2002).

Establishing a clear understanding of to whom the board is accountable is important for several reasons. A recent empirical study on the application of agency theory to nonprofit boards of directors in the United States reveals some of these reasons (Miller 2002). First, for nonprofit organizations, there are no clear owners. Certain parties make donations to the organization, and some suggest that those parties may serve as monitors of the board (Fama and Jensen 1983b), but they are not generally considered to "own" the organization. In addition, there is no residual claimant: instead, the board has a more general accountability to society. In her study, Miller found that some boards were able to articulate an "ownership" group-typically arising through the organization's perceived accountability to the community — while other boards only stated a general accountability to the 
board itself, founded in a responsibility to maintain the organization as a going concern.

For those boards that could articulate an ownership-like group, the trustees were able to meaningfully discuss the interests and expectations of that group. These board members recognized a clear mission for the organization and were able to keep their focus on that mission. By contrast, those boards that viewed themselves as only accountable to themselves were seen as less capable of fulfilling their oversight roles. While the board members recognized a fiduciary responsibility to the organization and the management of its finances, they did not know how to work toward these goals. Miller stated that for such boards, their "objectives for monitoring lack specificity." In addition, she found that board members would use the rhetoric of fulfilling fiduciary duties, but they usually uncritically accepted all of the information that was provided to them by management staff. These boards did not believe that they could change the organization's behavior and were less vigilant than the boards with an identified ownership group.

Boards thus need to have a clear and specific statement citing to whom they are accountable. Many pension funds have already identified this group as the plan participants, or have had this group identified for them by statute or regulation. If this "ownership" group is to be expanded, those other stakeholder groups that are to be included must be specified. Without a clear understanding of to whom it is accountable, the board is likely to be ineffective in monitoring or managing the fund.

\section{Performance Measures}

Related to accountability is the issue of how a board measures its performance. For corporations, performance can easily be measured by share value or return on investment. For public pension funds, however, the board could base its performance on funding levels, the size of investment return, achieving a set investment return target, reducing administrative costs, or some other measure (or any combination of these measures). Similar to the issue of identifying an ownership group, failure to specify a performance goal can lead to a less vigilant board of trustees. Miller's study of nonprofit organizations is again instructive on this issue.

For nonprofits, there is no widely accepted clear measure of performance. In her study, Miller found that some boards had developed a consensus on clear performance goals in such areas as budgetary issues, recruitment 
of donors, and the success of community service programs. Other boards, however, could not articulate a set of performance goals. For the boards with performance goals, the members had a better understanding of the information they needed to perform their oversight role and of how to use that information. For the boards that were unable to articulate performance goals, the members typically monitored them based on their personal skills. For example, board members who were lawyers in their professional lives considered the legal issues and accountant members considered the financial issues. These members gathered information they needed to fulfill these limited roles but had little knowledge of the performance of the organization outside these areas. In some cases, and even though they believed that they were fully informed, the trustees were not even aware of the programs operated by the organization. They were unaware of these programs because they did not involve issues related to their particular expertise. These members clearly lacked the necessary information to meaningfully monitor the organization, and their actions in addition did not focus on achieving any specific goal. As Miller stated, the focus of the board's actions were "primarily on form, not on substance." For the boards with criteria for measuring performance, however, a comprehensive strategic plan aimed at achieving those goals was easily developed.

\section{Roles of the Board}

The board may have control over a wide variety of decisions with respect to the fund, including the setting of actuarial assumptions, investment of fund assets, setting of benefits, and other decisions that relate to the management of the fund. In this sense, the governing board of a pension fund is more involved in the running of the organization than is a corporate board of directors. Where a corporate board may assist in the general setting of strategy, it serves mostly to provide advice to management and to monitor management's behavior on behalf of shareholders. In public pension funds, the board typically takes on an active management role, including delegation to professional managers, in addition to monitoring the pension fund staff.

In the United States, the board typically has authority over investment decisions. For example, a sample of state and local pension funds in 1998 showed 88 percent of funds to have investment authority. For the remaining 12 percent, investment decisions were most likely made by a state invest- 
ment board that is separate from the board of trustees. The board also usually had control over actuarial assumptions and benefits decisions (89 and 68 percent, respectively). The funds in our international survey showed a similar use of authority. The responses indicated that for 92 percent of the funds the board has authority over investments and for 77 percent it has authority over actuarial assumptions. In addition, 73 percent of the boards have authority over the selection of managers of fund activities.

One of the key roles of the board is to develop an investment strategy that maximizes returns at a risk level tolerable to the fund's stakeholders and that provides sufficient liquidity to meet benefit payment requirements (Mitchell 2002). To establish a strategy that is right for the fund, the board must decide how to allocate its assets and who will manage the funds: should it outsource to a private firm or employ the fund's own staff to conduct investments? The asset allocation decision involves many different factors, including the division between equities and fixed income investments, the level of diversification, the sectors of the economy in which to invest, whether or not to invest outside the borders of the country, and so on.

With respect to the use of investment managers, approximately 75 percent of U.S. state and local plans used external managers for all fund assets. From the international sample, only one fund of the 25 funds that responded to the question reported using external managers for all assets. The average fund used external managers for just 13 percent of its portfolio, but more than 50 percent of funds did not outsource any assets at all. Of those funds using external asset managers, less than 40 percent had explicit, written criteria for selecting managers. This creates the possibility of trustees granting asset manager awards based on political or personal preference, rather than on criteria that would identify managers most likely to act in the best interests of the plan participants. Overall, this evidence suggests that boards are keeping significant control over their fund's assets.

Some pension funds seek independence from political interference through the structure of their pension system and the assignment of different roles to different trustees. In Canada there are two separate entities, the Canada Pension Plan (CPP) and the CPP Investment Board (CPPIB), and two separate governing bodies. The CPP is the exclusive responsibility of the federal and provincial governments. These governments design, administer, and set policies for the plan for tasks such as the paying of benefits and the collection of contributions. The CPPIB is a separate organization that serves only to invest the funds of the CPP. Additionally, the CPPIB is gov- 
erned independently of government by professional managers and its own board of directors.

The boards of corporations often divide their work and assign primary responsibility for that work to separate committees, according to the different roles of each. Due to concerns over agency problems, it is recommended that key oversight committees, such as the compensation committee and the audit committee, be staffed by independent directors. For example, a compensation committee staffed by insiders may establish a CEO compensation and incentive plan that is overly generous; outside directors are more likely to exercise independent judgment and reduce such abuses. The boards of pension funds also use committees, but these are not as widespread as in the corporate world. For example, while all corporations are required to have an audit committee, less than half of the funds (45 percent) in our international sample used an audit committee. Sixty-four percent had an investment committee and 21 percent a governance committee. Governance committees are fairly new in corporate governance. While boards have typically had a nominating committee to assist the nomination of directors, more firms are switching to governance committees to which they can defer additional responsibilities, such as the establishment of board meeting agendas, adoption of guidelines for governance practices, selection of directors to serve on committees, and so on. In spite of the fact that only a few pension plans in our sample had governance committees, it is encouraging that pension managers are recognizing the importance of boards and are establishing proper board practices.

\section{Standards of Behavior}

Corporate boards of directors are subject to fiduciary duties, and failure to comply with those duties can result in legal liability. In the United States, private pension plans are subject to the strict fiduciary requirements of the Employee Retirement Income Security Act (ERISA) statute. ERISA's "exclusive benefit" (duty of loyalty) and "prudent person" (duty of care) rules require trustees to make sound, well-planned investment choices for the sole benefit of plan participants. For example, some have argued that it would be a breach of fiduciary duty for a private plan trustee to take into consideration certain social or community benefits when making investment decisions, because as a consequence such a decision could not be for the "exclusive benefit" of plan participants. 
Even though U.S. public pension plan trustees are not subject to ERISA, some commentators have argued that the common law of trusts establishes a fiduciary duty that is not significantly different from the ERISA standard (Romano 1993). In addition, many public pension plans are required by state law or internal policy to operate under the "prudent person" rule, which is a duty of care to act as a reasonably prudent person who is familiar with these matters in managing the investments of the fund. In the U.S. state and local sample, more than 90 percent of the funds operated under such a rule.

A key incentive to follow these standards is the existence of legal liability for actions that do not meet the standards. For example, the prudent person standard would likely not be met if a trustee made a significant investment decision without making the effort to first become reasonably informed about the decision. The trustee in such a situation could be legally liable for damages resulting from that breach of duty. More likely, however, is that pension fund trustees, like corporate directors, will be indemnified by the organization for any liability resulting from acts taken in good faith. In our international sample, the responses indicated that one-third of the funds did not maintain personal liability for trustees. For the other two-thirds of the funds, there is no legal liability. The consequence is that there is less incentive for the trustees to be vigilant in the performance of their duties.

Another tool with which to control the behavior of boards is a code of ethics (or conduct). During the 1980s and 1990s the maintenance of a code of ethics became standard practice for corporations, and more than 90 percent of large corporations now have such codes (Adams et al. 2001). Codes of ethics similarly have become increasingly common among public pension funds. Among the sample of U.S. state and local pension plans, the number of plans that used a code of ethics increased from 50 percent to 70 percent in the period 1992 to 1998.

Codes of ethics are expected to improve the performance of public pension funds. For trustees, the code cover such issues as conflicts of interest and the acceptance of gratuities. It should provide guidance to trustees and instruct them to avoid practices, such as the hiring of money managers based on favoritism, that may adversely affect plan members. Through such provisions it should guide trustees toward decisions based on prudence rather than personal gain, and this in turn should lead to better overall performance for the pension fund. Similar to the prudent person standard, a code of ethics should act as a control on agency problems. From the international sample, 52 percent of the funds have a code of conduct, 48 percent have conflict- 
of-interest rules, and 65 percent have one or the other. In New Zealand, trustees follow a code of conduct and are required to disclose any conflicts of interest they may have (Palacios 2002).

\section{Information and Transparency}

Information is an important and necessary part of behavioral controls. The trustees need information to perform their job with vigilance and the key stakeholder groups need information to hold the trustees accountable. As Eisenhardt (1989) stated, an agency perspective allows us to see that information is a commodity that can be purchased. Information should be provided up to the point where the marginal benefit of the information disclosure exceeds or equals the marginal cost of producing the information. As administrative costs can be significant in public pension plans, this is important. The information disclosed also should include explicit statements on the issues surrounding performance measures and accountability.

Information can come from many sources and pertain to many different items. Two key pieces of information are audits and annual reports. Audits provide the board with the information they need to perform their job appropriately and provide the public with the information they need to evaluate the financial health of the plan. Seventy percent of the funds in our sample produce an independent external audit on a regular basis. Likewise, annual reports provide the public with information on the actions of the board and the performance of the fund. All but one of the funds included in the sample indicated that they produce an annual report, and approximately half of the funds produce quarterly reports. In addition, 61 percent use an investment performance assessment.

To be useful, this information must of course be complete and accurate. In the United States, corporate securities laws dictate that management disclose all "material" information to shareholders and hold management liable for producing false information. In the context of corporate law, material information is that which a reasonable investor would consider important when making an investment decision. By law or policy, the board should specify what information is "material" for the stakeholders of the public pension fund. This should ensure that the disclosures provided by most pension funds do not omit any information that stakeholders would find useful.

Other relevant information includes the investment policies of the pension fund (63 percent of the funds in the international sample produce a 
written investment policy). Such policies provide the board both with guidance and possibly with performance goals. In our sample, the following items were included in the investment policy: short-term target rates of return (32 percent); long-term target rates of return (59 percent); quantified asset allocation guidelines (57 percent); and target measures of risk or volatility of returns ( 80 percent).

Included in the investment policy should also be a statement on the use of fund assets for social goals. As noted by Iglesias and Palacios (2002), most funds do not have established criteria for social investments. In some cases, the fund is prevented by law from investing in any way other than that which maximizes profit. For funds without such restrictions, there should be established criteria for when goals other than those pertaining to the maximizing of value can be taken into consideration. For example, many have pointed out the potential distortion that large pension funds could cause to smaller capital markets. Funds could include in their policy the explicit identification of situations where such social and local economic issues should be taken into consideration.

\section{Conclusion}

Agency theory has been useful for understanding and improving the governance of corporations. Likewise, it should be useful for improving the governance of public pension funds. However, just as there is not a onesize-fits-all governance structure for corporations throughout the world, or even within a single country, there is no single governance structure that can be universally applied to public pension funds. Different goals, restrictions, political environments, and local market conditions; the availability of competent asset managers; and many other factors will affect the appropriate governance structure for any pension fund, but it is important that the board recognize potential agency problems-whether they are based on uncertainty or on potential goal conflicts-and then utilize the appropriate governance control mechanisms.

Different asset allocations will require different governance practices, for example. Using our survey results, we compared those funds that allocate more than 10 percent of their assets to equities with the funds that do not. The funds with more 10 percent of their portfolio in equities were more likely to provide their trustees with written conflict-of-interest rules. In 
addition, these funds operated more transparently: they were more likely to have written disclosure rules and more likely to regularly produce independent external audits and actuarial reports.

These differences suggest that funds recognize the potential for agency problems when investing in equities and the need for governance mechanisms to prevent these problems. For example, with equity investments there is a greater chance that trustees may purchase securities from individuals or businesses with which they have financial or political ties. In response, pension funds may adopt conflict-of-interest rules to mitigate this problem. Such rules would be not as necessary if the funds could be invested more heavily in government bonds. Interestingly, the funds with more equity investments had significantly fewer elected trustees. One possible explanation for this finding is that such funds favor the appointment of trustees as a means of ensuring that the board has the expertise necessary to invest in equities.

Overall, developing an understanding of agency theory and the various mechanisms that can control the agency problems that potentially exist in public pensions would enable pension fund sponsors to adopt the optimal governance tools at the lowest administrative cost.

\section{References}

Adams, Janet S., Armen Tashchian, and Ted H. Stone. 2001. "Codes of Ethics as Signals of Ethical Behavior." Journal of Business Ethics 29(3):199-211.

American Law Institute. 1995. Principles of Corporate Governance. St. Paul, Minnesota: American Law Institute Publishers.

Becht, Marco, Patrick Bolton, and Alisa Röell. 2002. "Corporate Governance and Control." NBER (National Bureau of Economic Research) Working Paper 9371. Cambridge, Massachusetts: NBER.

Besley, Timothy, and Andrea Prat. 2002. "Pension Fund Governance and the Choice Between Defined Benefit and Defined Contribution Plans." London School of Economics. Processed.

Bhagat, Sanjai, and Bernard Black. 1999. "The Uncertain Relationship between Board Composition and Firm Performance." Business Lawyer 54:921-963. 
Brinson, Gary P., L. Randolph Hood, and Gilbert L. Beebower. 1986. "Determinants of Portfolio Performance." Financial Analysts Journal 42:39-44.

Brinson, Gary P., Brian D. Singer, and Gilbert L. Beebower. 1991. "Determinants of Portfolio Performance II: An Update." Financial Analysts Journal 47:40-48.

Caprio, Jr., Gerard, and Ross Levine. 2002. "Corporate Governance in Finance: Concepts and International Observations." Paper presented at the 2002 World Bank, IMF, and Brookings Institution Conference, Building the Pillars of Financial Sector Governance: The Roles of Public and Private Sectors.

Carmichael, Jeffrey. 2002. "Building the Pillars of Financial Sector Governance: The Roles of the Public and Private Sectors." Paper presented at the 2002 World Bank, IMF, and Brookings Institution Conference, Building the Pillars of Financial Sector Governance: The Roles of Public and Private Sectors.

Chia, Ngee Choon, and Albert K. C. Tsui. 2003. "Life Annuities of Compulsory Savings and Income Adequacy of the Elderly in Singapore." Journal of Pension Economic and Finance 2(1): 41-65.

Davis, Gerald F., and Michael Useem. 2000. "Top Management, Company Directors, and Corporate Control." In Andrew Pettigrew, Howard Thomas, and Richard Whittington (eds.): Handbook of Strategy and Management. London: Sage.

Dei, Henry. 2001. "Public Pension Fund Management in Ghana." Paper presented at the 2001 World Bank Public Pension Fund Management Conference. Available online at www.worldbank.org/finance.

Eisenhardt, Kathleen M. 1989. "Agency Theory: An Assessment and Review." Academy of Management Review 14(1):57-74

Fama, Eugene F. 1980. "Agency Problems and the Theory of the Firm." Journal of Public Economics 88(2):288-307.

Fama, Eugene F., and Michael C. Jensen. 1983a. "Agency Problems and Residual Claims." Journal of Law and Economics 26(2):327-49.

- 1983b. "Separation of Ownership and Control." Journal of Law and Economics 26(2):301-25.

GAO (United States Government Accounting Office). 1995. "Public Pension Plans: Evaluation of Economically Targeted Investment Programs." GAO/PEMD 95-13. 
Iglesias, Augusto, and Robert J. Palacios. 2000. "Managing Public Pension Reserves. Part I: Evidence from the International Experience." Social Protection Discussion Paper 3. Washington, D.C.: World Bank. Jensen, Michael C., and William H. Meckling. 1976. "Theory of the Firm:

Managerial Behavior, Agency Costs, and Ownership Structure.” Journal of Financial Economics 3:305-60.

Levinthal, Daniel. 1988. "A Survey of Agency Models of Organization." Journal of Economic Behavior and Organization 9:153-185.

Lin, Laura. 1996. "The Effectiveness of Outside Directors as a Corporate Governance Mechanism: Theories and Evidence." Northwestern Law Review 90:898-976.

Lorsch, Jay W., and Elizabeth MacIver. 1989. Pawns or Potentates: The Reality of America's Corporate Boards. Boston, Massachusetts: Harvard Business School Press.

MacNaughton, John. 2001. "Principles and Practices of Governance for Public Pension Funds." Paper presented at the 2001 World Bank Public Pension Fund Management conference. Available online at www.worldbank.org/finance.

Main, Brian G. M., Charles A. O'Reilly III, and James Wade. 1995. "The $\mathrm{CEO}$, the Board of Directors, and Executive Compensation: Economic and Psychological Perspectives." Industrial and Corporate Change 4:293332.

Mayers, David, Anil Shivdasani, and Clifford W. Smith, Jr. 1997. "Board Composition and Corporate Control: Evidence from the Insurance Industry." Journal of Business 70(1):33-62.

Miller, Judith L. 2002. "The Board as a Monitor of Organizational Activity: The Applicability of Agency Theory to Nonprofit Boards." Nonprofit Management and Leadership 12(4): 429-450.

Mitchell, Olivia S. 2002. Redesigning Public Sector Pensions in Developing Countries." Pension Research Council Working Paper 2002-9. University of Pennsylvania.

Murphy, Kevin J., and Karen Van Nuys. 1994. "Governance, Behavior, and Performance of State and Corporate Pension Funds.” Working Paper: Harvard University.

Nofsinger, John R. 1998. "Why Targeted Investing Does Not Make Sense!"

Financial Management 27(3):87-96. 
Palacios, Robert J. 2002. "Managing Public Pension Reserves Part II: Lessons from Five Recent OECD Initiatives." Social Protection Discussion Paper 219. Washington, D.C.: World Bank.

Romano, Roberta. 1993. "Public Pension Fund Activism in Corporate Governance Reconsidered." Columbia Law Review 93:795-853.

- 1995. "The Politics of Public Pension Funds." The Public Interest 119: 42-53.

- 2001. "Less is More: Making Institutional Investor Activism a Valuable Mechanism of Corporate Governance." Yale Journal on Regulation 18: 174-251.

Shivdasani, Anil, and David Yermack. 1999. "CEO Involvement in the Selection of New Board Members: An Empirical Analysis." Journal of Financial Economics 54:1,829-1,853.

Shleifer, Andrei, and Robert W. Vishny. 1997. "A Survey of Corporate Governance." Journal of Finance 52(2):737-783.

Singh, H., and F. Harianto. 1989. "Management-Board Relationships, Takeover Risk, and the Adoption of Golden Parachutes." Academy of Management Journal 32:7-24.

Stevenson, Richard W. 1992. "Pension Funds Becoming a Tool for Growth." New York Times, March 17, 1992, at D1.

Vise, David A. 1992. "A Billion-Dollar Battle over Pension Plans' Purpose." The Washington Post, December 6, 1992, at H1.

Wade, James, Charles A. O'Reilly, III, and Ike Chandratat. 1990. "Golden Parachutes: CEOs, and the Exercise of Social Influence." Administrative Science Quarterly 35:587-603.

Walsh, Mary Williams. 2002. "CalPERS Wears a Party, or Union, Label." New York Times, October 13, 2002.

Watson, Ronald D. 1994. "Does Targeted Investing Make Sense?" Financial Management 23:69-74.

Westphal, James D., and Edward J. Zajac. 1995. "Who Shall Govern? CEO/ Board Power, Demographic Similarity, and New Director Selection." Administrative Science Quarterly 40:60-83.

Zajac, Edward J., and James D. Westphal. 1996. "Director Reputation, CEOBoard Power, and the Dynamics of Board Interlocks." Administrative Science Quarterly 41:507-529. 


\section{Notes}

1. The questionnaire used for this survey can be found in the working paper version of this paper at econ.worldbank.org.

2. This analysis - and later discussions of U.S. state and local pension plans-uses survey-based data collected by the Government Finance Officers Association from 1990 to 2000. This data set is commonly referred to as "Pendat." 
